\title{
Predicting the Impact of Climate Change on Kulfo River Flow
}

\author{
Nega Gudeta Demmissie ${ }^{1,}$, Tamene Agugna Demissie ${ }^{2}$, Fayera Gudu Tufa ${ }^{2}$ \\ ${ }^{1}$ Department of Hydraulic and Water Resources Engineering, Mizan- Tepi University, Tepi, Ethiopia \\ ${ }^{2}$ Department of Hydraulic and water Resources Engineering, Jimma University, Jimma, Ethiopia
}

\section{Email address:}

gudeta2nega@gmail.com (N. G. Demissie), tamene_adu2002@yhahoo.com (T. A. Demissie), fayerag2@gmail.com (F. G. Tufa)

*Corresponding author

\section{To cite this article:}

Nega Gudeta Demmissie, Tamene Agugna Demissie, Fayera Gudu Tufa. Predicting the Impact of Climate Change on Kulfo River Flow. Hydrology. Vol. 6, No. 3, 2018, pp. 78-87. doi: 10.11648/j.hyd.20180603.11

Received: October 10, 2018; Accepted: November 10, 2018; Published: December 19, 2018

\begin{abstract}
Assessment of the potential impact of climate change on hydrology and water resources of rivers is important for future planning and management of water resources. The objective of this paper is to predict the impact of climate change on stream flow of Kulfo River. This study used Soil and Water Assessment Tool (SWAT) model and hypothetical climate change scenarios based on the fifth assessment report of Intergovernmental Panel on Climate Change (IPCC) and by review different research papers on climate change to investigate the current and two future scenarios 2050s and 2080s stream flow magnitude in the River. The SWAT mode was calibrated and Validated against stream flow and attained coefficient of determination 0.81 and 0.92, and Nash Sutcliffe Efficient of 0.68 and 0.78 during calibration and validation respectively. The hypothetical climate scenarios were compared to the observed baseline period (1987-2014) and the potential impact of climate change on stream flow quantified as, the average annual stream flow of Kulfo River is projected to increase by $5.42 \%$, in $2050 \mathrm{~s}$. In contrast it was found to give the maximum decrease in discharge by $-8.2 \%$ in $2080 \mathrm{~s}$. Increasing temperature by $0.5^{\circ} \mathrm{C}$ decreased stream flow rates by $2.99 \%$ in 2050 s while $10 \%$ drops in rainfall resulted in a stream flow reduction by $5.28 \%$ in 2080 s. Overall, the results show that stream flow in the Kulfo River will be more sensitive to change in precipitation than change in temperature.
\end{abstract}

Keywords: Climate Change Impact, Hydrologic Model, Stream Flow, SWAT Model

\section{Introduction}

Changes in precipitation patterns and air temperature due to climate change may alter the availability (quality and quantity) of water leading to new challenges for water resource planning and management in many regions throughout the world $[1,2]$. Nowadays, there is strong scientific evident that the average temperature of the Earth's surface is increasing due to greenhouse gas emissions. The Fifth Assessment Report (AR5) of the Intergovernmental Panel on Climate Change (IPCC 2015) on climate change points out that the average annual global surface air temperature for 2081-2100 relative to $1986-2005$ is projected to likely be higher in the ranges $2.6^{\circ} \mathrm{C}$ to $4.8^{\circ} \mathrm{C}$ under high emission scenarios while sea level has risen by the year 2100 is 0.52 to $0.98 \mathrm{~m}$, and these increases have been partially attributed to the accumulation of greenhouse gases in the atmosphere [3]. Such changes could affect the hydrological cycle. The hydrological cycle plays a key role in regulating the dynamics of natural systems. As a country, Ethiopia is referred as a water tower of Northeast Africa. Ethiopia has twelve major river basins as shown in figure 1.

Climate change will reduce water availability, hydropower potential and changing seasonality of flows in many regions [5, 6]. Thus, understanding climate change and its impact on stream flow is important for water resources management. Literature on the application of adaptation measures to changing climatic conditions is very limited and the need for more work is evident on the development of adaptation strategies for mitigating negative impacts of climate change in water resources management practice [4].

Identifying the trends and relationships between rainfall, temperature and stream flow is fundamental to understanding the influence of climate change on the river discharge. Many studies [3, 32-37] have shown that rainfall is the first 
atmospheric factor that directly affects the stream flow. There are also a number of studies [34-37] which found that changes in rainfall are not sufficient to explain the trends in the stream flow.

In this study, Kulfo Rive in the Abaya-Chamo sub-basin of the southern Ethiopian Rift Valley, which is one of the most sensitive areas to climate change, is selected as the study area $[7,8]$. Due to these reasons climate change has become a major topic of interest. The objective of this study is to predict climate change impacts on stream flow of Kulfo River, by using hydrological models, SWAT (Soil and Water Assessment Tool) with assumed plausible hypothetical climatic input scenarios according to the IPCC fifth assessment report.

Section 2 presents the location of the study area, data types and sources, as well as the methods used in this study and provides brief descriptions of the SWAT model. The study results, including the parameters sensitivity analysis, calibration and validation of the model simulated stream flow under climate change and Stream Flow Sensitivity Analysis are presented and discussed in Section 3. Finally, the conclusions of present study are discussed in Section 4.

\section{Materials and Methods}

\subsection{Study Area}

The study area, Kulfo River watershed is located in Gamo-Gofa zone, South Nation, Nationality People Region regional state, with in the Abaya-Chamo sub-basin of the southern Ethiopian Rift Valley. The watershed is situated between $5^{\circ} 58^{\prime} \mathrm{N}-6^{\circ} 18^{\prime} \mathrm{N}$ latitude and $37^{\circ} 18^{\prime} \mathrm{E}-37^{\circ} 38^{\prime} \mathrm{E}$ longitude; and has a land area of $391 \mathrm{~km}^{2}$. Kulfo River is a tributary of the Lake Chamo system, draining the western Garbsen shoulder and joining Lake Abaya-Lake Chamo just in the transition zone $[9,10]$.

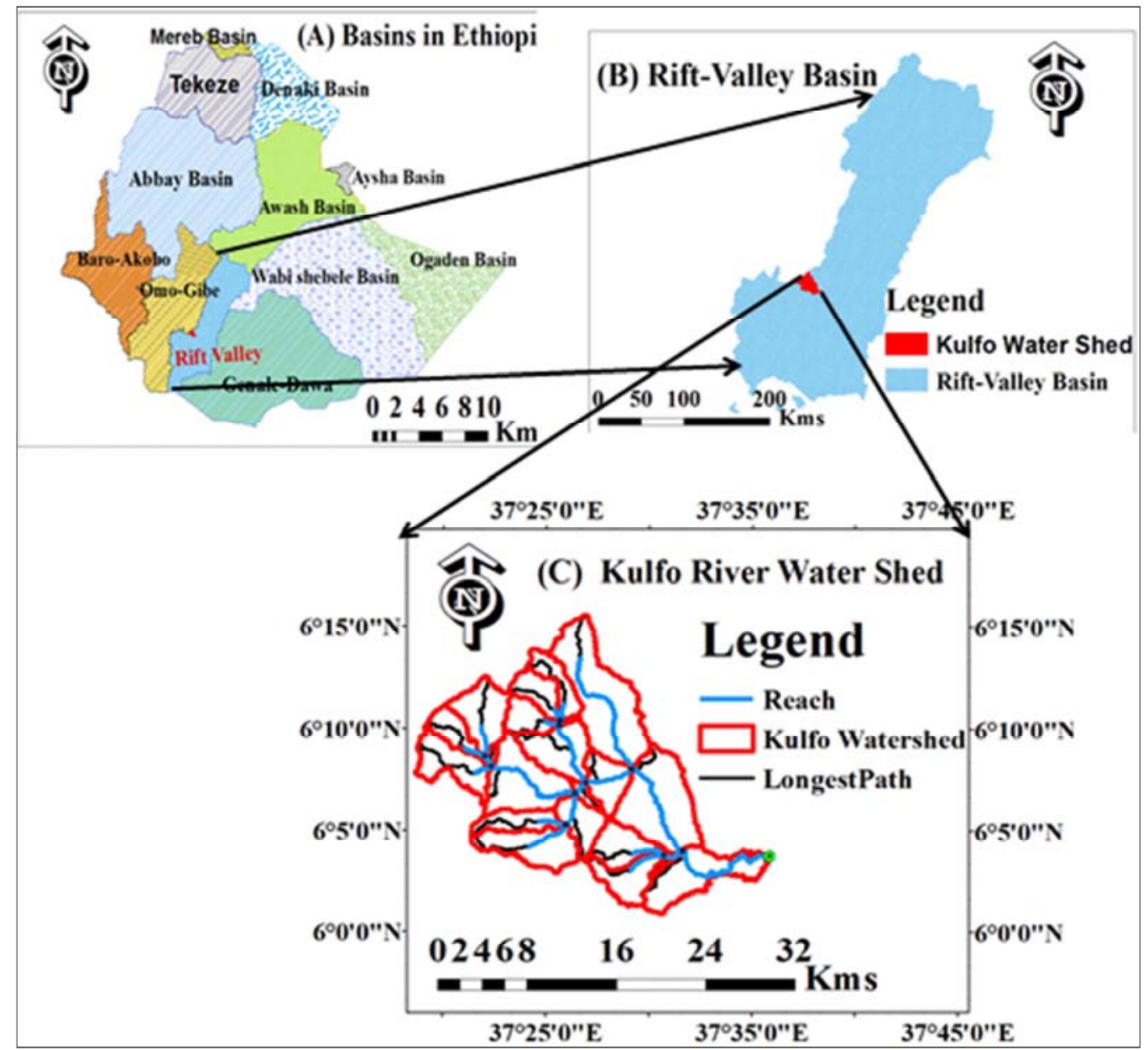

Figure 1. Location of Kulfo River.

\subsection{Data Availability}

The necessary input data required for the setup of the SWAT model were weather data, hydrological data, Climatic Scenario data and spatial data which were collated from different sources.

\subsubsection{Weather Data and Hydrological Data}

The weather data such as daily precipitation, daily maximum and minimum temperature, sunshine hour, relative humidity and daily wind speed were collected from the Ethiopian National Meteorology Service Agency. These data were used as the input to the SWAT hydrological model for the 
simulation of the hydrological components.

SWAT simulates stream flow, sediment yield, nutrient and pesticide transport at catchment scale, on a continuous, daily time step [11]. Hydrological data were required for calibration and validation of the SWAT model. Daily observed flow data were collected from the Hydrology Department of Ministry of Water, Irrigation and Electricity.

\subsubsection{Climatic Scenario Data}

Hypothetical or synthetic scenarios which develops by changing the particular climate element in plausible and arbitrary amount (e.g. $+2^{\circ} \mathrm{C},+4^{\circ} \mathrm{C}$ change from the baseline temperature and $\pm 5 \%, \pm 10 \%, \pm 20 \%$ change from the baseline precipitation) [12]. For this particular study [12], were adopted in order to analysis the sensitivity of stream flow towards climate change. Based on the IPCC Fifth assessment Reports and different literatures on climate, the temperature range for $2050 \mathrm{~s}\left(+2.5^{\circ} \mathrm{C}\right.$ to $\left.3^{\circ} \mathrm{C}\right)$ and for $2080 \mathrm{~s}\left(+4^{\circ} \mathrm{C}\right.$ to $\left.5^{\circ} \mathrm{C}\right)$ is adopted for present study. The precipitation ranges based on study presented by Abraham et al. and Habtom is adopted as ($20 \%$ to $+20 \%)[13,14]$.

\subsubsection{Spatial Data}

Digital elevation model (DEM) of $30 \mathrm{~m}$ by $30 \mathrm{~m}$ SRTM was downloaded from the USGS (earth explorer.usgs.gov) website in raster form. Catchment characteristics like slope gradient, stream network and stream characteristics were derived from the DEM using the automatic watershed delineation tool in Arc SWAT. The land use /land cover data and soil data were collected from GIS department of Ministry of Water, Irrigation and Electricity. Necessary corrections and projection have been made for spatial data in GIS environment.

\subsection{Study Design}

The main tools used for model input data preparation were: Arc SWAT (2012), SWAT-CUP (2012) Version 5.16, PCPSTAT.exe, Dew02.exe, and New_LocClim_1.10 (Local Climate Estimator version 1.10). The methodology followed in the current study can be described as follow: Data collection, data preparation, running model, sensitivity analysis, calibration and validation of the model, model performance evaluation, model result analysis, scenario selection and finally checking climate change impact on stream flow. In order to understand how each part works within the modelling process, it is important to know the conceptual framework of each step, as well as what data are used and how they are integrated in to Arc SWAT.

\subsection{SWAT Model Description}

Soil and Water Assessment Tool (SWAT) [15] is a comprehensive, semi-distributed river basin model that requires a large number of input parameters, which complicates model parameterization and calibration. SWAT operates on a daily time step and is designed to predict the impact of land use and management on water, sediment, and agricultural chemical yields in un gauged watersheds [16]. All these characteristics of the model along with the fact that the data needed for setting up the model for this work in the study area are available make the choice of the SWAT model appropriate. SWAT can be used to examine large or small catchments by discretizing them into sub-basins, which are then additionally sub-divided for modelling determination the catchments are separated into a number of sub-basins which will be divided into hydrological response units (HRUs) each having unique land use, soil types, and management and slope characteristics.

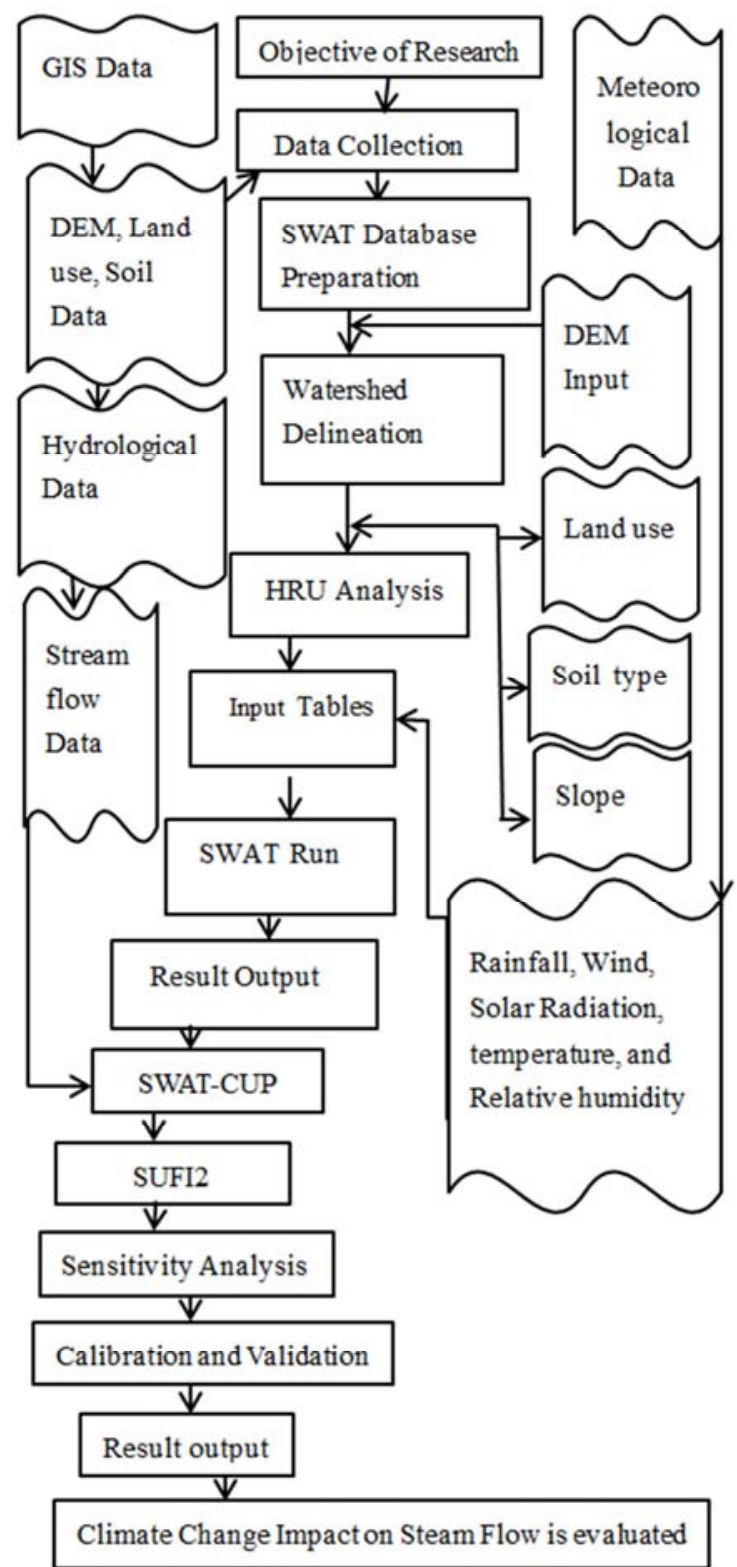

Figure 2. Flow chart of Arc SWAT processing steps.

SWAT simulate the hydrologic process based on the water balance equation [17].

$$
S W t=\mathrm{SW}_{0}+\sum_{\mathrm{i}=1}^{\mathrm{t}}\left(\mathrm{R}_{\text {day }}-\mathrm{Q}_{\text {surf-E }}-\mathrm{W}_{\text {seep }}-\mathrm{Q}_{\mathrm{gw}}\right)
$$

Where: $\mathrm{SW}_{\mathrm{t}}=$ the final soil water content $(\mathrm{mm}), \mathrm{SW}_{\mathrm{o}}=$ the initial water content $(\mathrm{mm}), \mathrm{t}=$ the time (days), $R_{\text {day }}=$ the 
amount of precipitation on day $\mathrm{i}(\mathrm{mm}), \mathrm{Q}_{\text {surf }}=$ the amount of surface runoff on day $\mathrm{i}(\mathrm{mm}), \mathrm{Ea}=$ the amount of evapotranspiration on day $\mathrm{i}(\mathrm{mm}), \mathrm{W}_{\text {seep }}=$ the amount of water entering the vadose zone from the soil profile on day $\mathrm{i}(\mathrm{mm})$, $\mathrm{Q}_{\mathrm{gw}}=$ the amount of return flow on day $\mathrm{i}(\mathrm{mm})$.

SWAT provides two methods for modelling surface runoff. The Soil Conservation Service (SCS) curve number [18] and the Green and Ampt infiltration method [19]. The method used for this work is the curve number method due to the daily based data that we have for the study.

\subsection{SWAT-CUP}

SWAT-CUP is specially developed by Abbaspour to interface with the SWAT model [20]. Any calibration/uncertainty or sensitivity program can easily be linked to SWAT model by using this generic interface. In this study, the SUFI-2 algorithm was used to investigate sensitivity in stream flow prediction. A multiple regression system with Latin hypercube samples by means of objective function values was used in calculating the responsive parameter sensitivities, with the detailed method specified by [21]. The $t$-test and the $p$-values were used to provide a measure and the significance of the sensitivity, respectively. The larger in absolute values are more sensitive than the lower ones, while a value closer to zero has more significance [22].

\subsection{Sensitivity Analysis}

Parameters identified in sensitivity analysis that influence predicted outputs are often used to calibrate a model [23]. Therefore sensitivity analysis as an instrument for the assessment of the input parameters with respect to their impact on model output [24]. The main purpose of sensitivity analysis is to understand the model behavior in response to variations of different calibration parameter [4].

\subsection{Model Calibration and Validation}

Model calibration is a means of adjusting or fine tuning model parameters to match with the observed data as much as possible, with limited range of deviation accepted. Similarly, model validation is testing of calibrated model results with independent data set without any further adjustment at different spatial and temporal scales. As the model predictive capability was demonstrated as being reasonable in both the calibration and validation phases, the model was used for future predictions under different management scenario [25]. The statistical criteria ( $\mathrm{R}^{2}$ ), NSE), ( PBIAS) and (RSR) are used to make sure that the simulated values is within the accuracy range.

\subsection{Model Performance Evaluation}

The performance of a model must be evaluated on the extent of its accuracy, consistency, and adaptability [26]. The performance of the model in simulating stream flow is evaluated using SWAT-CUP. According to Moriasi, the analysis use four commonly used goodness-of-fit tests [27] as follow:

Coefficient of Determination $\left[\mathrm{R}^{2}\right]$ : The coefficient of determination, denoted by $\mathrm{R}^{2}$, it provides a measure of how well observed outcomes are explained by the prediction. A value of zero means no correlation at all, whereas one means the prediction is equal to that of the observation [27]. It is given by:

$$
\mathrm{R}^{2}=\left[\frac{\sum_{\mathrm{t}=1}^{\mathrm{n}}\left(\mathrm{Q}^{\text {obs }}-\mathrm{Q}^{\text {obs mean }}\right)\left(\mathrm{Q}^{\text {simu }}-\mathrm{Q}^{\text {simu mean }}\right)}{\left(\sum _ { \mathrm { t } = 1 } ^ { \mathrm { n } } ( \mathrm { Q } ^ { \text { obs } } - \mathrm { Q } ^ { \text { obs mean } } ) ^ { 2 } * \left(\sum_{\mathrm{t}=1}^{\mathrm{n}}\left(\mathrm{Q}^{\text {simu }}-\mathrm{Q}^{\text {simu mean }}\right)^{2}\right.\right.}\right]^{2}
$$

Where: $\mathrm{n}$ is umber of observed data points, $\mathrm{R}^{2}$ is coefficient of determination, $\mathrm{Q}^{\text {obs }}$ is the observed flow $\left(\mathrm{m}^{3} / \mathrm{s}\right), \mathrm{Q}^{\text {obs mean }}$ is the mean of observed flow $\left(\mathrm{m}^{3} / \mathrm{s}\right), \mathrm{Q}^{\mathrm{simu}}$ is the simulated flow $\left(\left(\mathrm{m}^{3} / \mathrm{s}\right)\right.$ and $\mathrm{Q}^{\text {simu mean }}$ is the mean of simulated flow $\left(\mathrm{m}^{3} / \mathrm{s}\right)$.

Nash-Sutcliffe coefficient (NSE): Nash-Sutcliffe coefficient measures the efficiency of the model by relating the goodness of fit of the model to the variance of the measured data, Nash-Sutcliffe efficiencies can range from $-\infty$ to 1 . An efficiency of 1 corresponds to a perfect match of simulated discharge to the observed data. An efficiency of 0 indicates that the model predictions are as accurate as the mean of the observed data [28]. The formula for Nash Sutcliffe (NSE) is:

$$
\mathrm{NSE}=1-\left[\frac{\sqrt{\sum_{\mathrm{t}=1}^{\mathrm{n}}\left(\mathrm{Q}_{\mathrm{i}}^{\text {obs }}-\mathrm{Q}_{\mathrm{i}}^{\text {simu }}\right)^{2}}}{\sqrt{\sum_{\mathrm{t}=1}^{\mathrm{n}\left(\mathrm{Q}_{\mathrm{i}}^{\text {obs }}-\mathrm{Q}_{\text {obs }}{ }^{\text {mean }}\right)^{2}}}}\right]
$$

Where: NSE is Nash-Sutcliffe coefficient, $Q^{\text {obs }}$ is the observed flow $\left(\mathrm{m}^{3} / \mathrm{s}\right), \mathrm{Q}^{\text {mean }}$ is the mean of observed flow $\left(\mathrm{m}^{3} / \mathrm{s}\right), \mathrm{Q}^{\mathrm{simu}}$ is the simulated flow $\left(\mathrm{m}^{3} / \mathrm{s}\right)$, and $\mathrm{n}$ is umber of observed data points.

Percent bias ( PBIAS): Percent bias measures the average tendency of the simulated data to be larger or smaller than their observed counterparts. The optimal value of PBIAS is 0 , with low-magnitude values indicating accurate model simulation. Positive values indicate model underestimation bias, and negative values indicate model overestimation bias [27]. PBIAS is calculated with the following equation:

$$
\text { PBIAS }=\left[\frac{\sqrt{\sum_{\mathrm{t}=1}^{\mathrm{n}}\left(\mathrm{Q}_{\mathrm{i}}^{\text {obs }}-\mathrm{Q}_{\mathrm{i}}^{\text {simu }}\right) *(100)}}{\sqrt{\sum_{\mathrm{t}=1}^{\mathrm{n}}\left(\mathrm{Q}_{\mathrm{i}}^{\text {obs }}\right)}}\right]
$$

Where: PBIAS is the deviation of data being evaluated expressed as a percentage, $Q_{\mathrm{i}}^{\text {obs }}$ is the observed value and $\mathrm{Q}_{\mathrm{i}}^{\text {simu }}$ is the simulated value.

Observations Standard Deviation Ratio (RSR): Observations Standard Deviation Ratio (RSR), RSR is calculated as the ratio of the root mean square error and standard deviation of measured data, as shown in the following equation:

$$
R S R=\frac{R M S E}{S T D E V o b s}=\left[\frac{\sqrt{\sum_{t=1}^{n}\left(Q_{I}^{o b s}-Q_{i}^{\text {simu }}\right)^{2}}}{\sqrt{\sum_{t=1}^{n}\left(Q_{i}^{o b s}-Q^{\text {mean }}\right)^{2}}}\right]
$$

Where: STDEVobs is standard deviation of observed data of the constituent being evaluated, $Q_{I}^{\text {sim }}$ is the $i^{\text {th }}$ simulated value for the constituent being evaluated, $Q_{i}^{\text {obs }}$ is the $i^{\text {th }}$ observation for the constituent being evaluated, $Q^{\text {mean }}$ is the mean of observed data for the constituent being evaluated, $n$ is the total number of observation. RSR varies from the optimal value of 0 , which indicates zero RMSE or residual 
variation and therefore perfect model simulation, to a large positive value. Moriasi suggested a general performance rating for the recommended statistics for a monthly time step for SWAT model [27].

Table 1. Performance ratings of recommended statistics for monthly stream flow.

\begin{tabular}{llll}
\hline Performance rating & RSR & NSE & PBIAS (\%) \\
\hline Very good & $0 \leq \mathrm{RSR} \leq 0.5$ & $0.75<\mathrm{NSE} \leq 1$ & PBIAS $<10$ \\
Good & $0.5<\mathrm{RS} \leq 0.6$ & $0.65<\mathrm{NSE} \leq 0.75$ & $10 \leq \mathrm{PBIAS}<15$ \\
Satisfactory & $0.6<\mathrm{RSR} \leq 0.7$ & $0.5<\mathrm{NS} \leq 0.65$ & $15 \leq \mathrm{PBIAS}<25$ \\
Unsatisfactory & $\mathrm{RSR}>0.70$ & $\mathrm{NSE} \leq 0.5$ & PBIAS $\geq 25$ \\
\hline
\end{tabular}

\section{Results and Discussion}

\subsection{Model Sensitivity Analysis}

Twenty seven SWAT parameters were considered for the model parameterization and sensitivity analysis. The most sensitive parameters were identified using global sensitivity analysis method in SWAT-CUP, SUFI2 as suggested by Abbaspour [22]. The top eight most sensitive parameters were used for stream flow calibration and validation. The most eight sensitive parameters were selected based on $t$-stat and $p$-values. A $t$-stat provides a measure of sensitivity (larger in absolute value are more sensitive), whereas $p$-values the significance of the sensitivity, a value close to zero is more significant.

Table 2. Results of the sensitive parameters of Kulfo River (sensitive parameters, $t$-stat, P-value, sensitivity rank, maximum, minimum and fitted values using SUFI2).

\begin{tabular}{|c|c|c|c|c|c|c|c|}
\hline No & Parameters Name & t-Stat & P-Value & Fitted Value & Min value & Max value & Sensitivity Rank \\
\hline 1 & CN2.mgt & -17.5 & 0.000 & -0.85 & -0.2 & 0.2 & 1 \\
\hline 2 & ALPHA_BF.gw & -8.90 & 0.000 & 0.24 & 0 & 1 & 2 \\
\hline 4 & GW_DELAY.gw & 1.18 & 0.239 & 372.3 & 30 & 450 & 4 \\
\hline 5 & ESCO.hru & -1.16 & 0.247 & 0.96 & 0.8 & 1 & 5 \\
\hline 6 & SOL_AWC.sol & 0.34 & 0.735 & -0.09 & -0.2 & 0.4 & 6 \\
\hline 7 & GWQMN.gw & -0.32 & 0.753 & 0.50 & 0 & 2 & 7 \\
\hline 8 & REVAPMN.gw & -0.084 & 0.933 & 2.41 & 0 & 10 & 8 \\
\hline
\end{tabular}

Based on A t-test and p-value, from the model out put the first three most sensitive parameters are SCS runoff curve number (CN2), Base flow alpha factor (ALPHA_BF) and Effective hydraulic conductivity of the main channel (CH_K2). The remaining parameters such as, Ground water Delay (GW_DELAY), Soil evaporation compensation factor (ESCO), Soil available water capacity (SOL_AWC), the threshold depth of water in shallow aquifer required for return flow (GWQMN) and threshold depth of water in the shallow aquifer for "revap" to occur (REVAPMN) are the $4^{\text {th }}, 5^{\text {fth }}, 6^{\text {th }}$, $7^{\text {th }}$ and $8^{\text {th }}$ sensitive parameters respectively.

\subsection{Assessment of the Performance of SWAT Model in Simulation of Stream Flow}

\subsubsection{Calibration of Monthly Stream Flow}

After the sensitive parameters identification, calibration of the model was executed to evaluate the performance of the model simulation using automatic calibration tools (SWAT-CUP SUFI2) algorithms. The calibration processes were considered 8 most sensitive parameters as shown in table 2 and their values were varied iteratively within the allowable ranges until satisfactory agreement between measured and simulated stream flow was obtained. The calibration results show that the coefficient of determination $\left(\mathrm{R}^{2}\right)$ and Nash-Sutcliff Efficient (NSE) is 0.81 and 0.68 respectively. These are according to Moriasi suggestion the performance rating is under very good and good respectively [27]. The researchers also consider Standard Deviation Ratio (RSR) and
Percent Bias (PBIAS). In present study RSR $=0.57$ and PBIAS $=20 \%$ which is in the range of good and satisfactory respectively.

The comparison of the observed and simulated stream flow for Kulfo River during the calibration period was presented in figure 3 . The time series data of the observed and simulated flows on monthly basis were plotted for visual comparison and the scatter plot of monthly stream flow showing a good-fitting relationship of the observed and simulated values for calibration as shown in figure 4 .

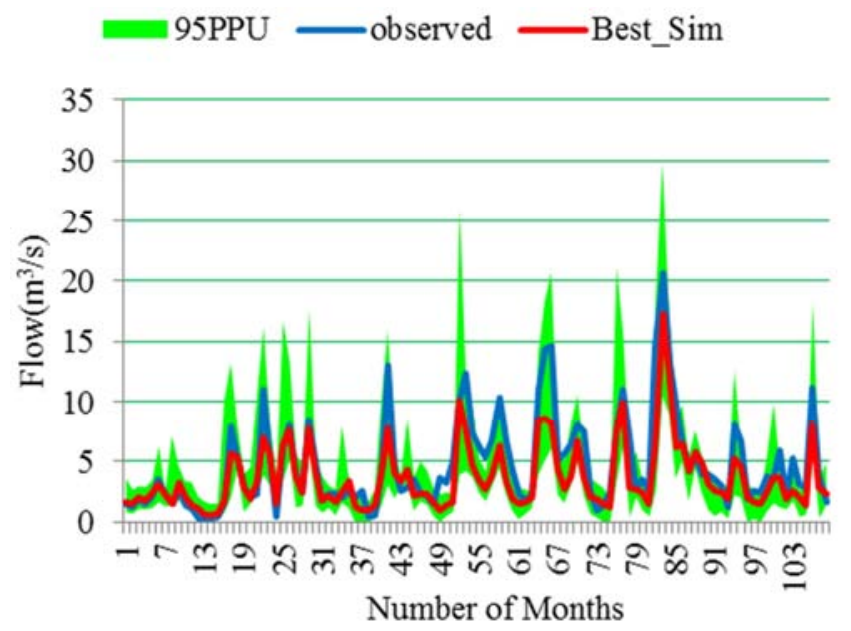

Figure 3. Average monthly observed and simulated stream flows of Kulfo River during calibration period (1991-1999). 


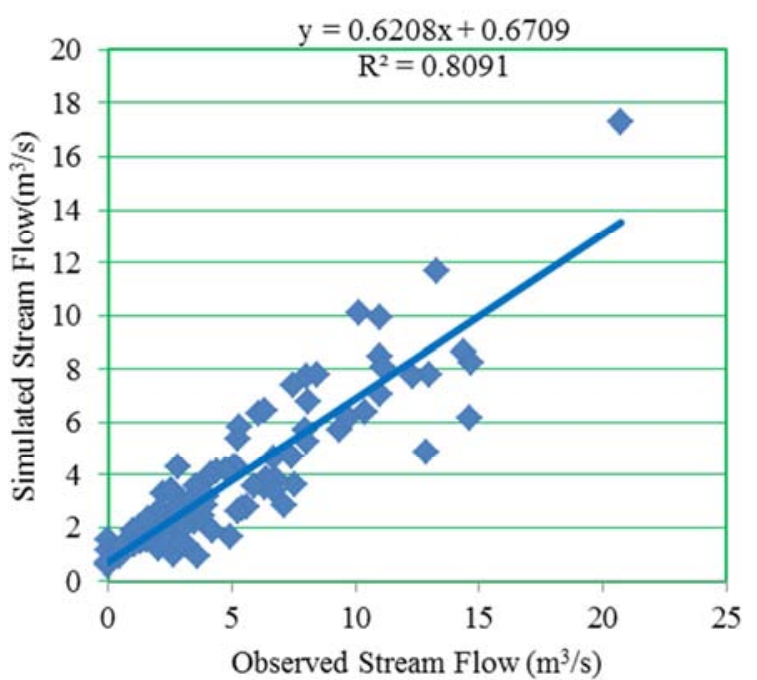

Figure 4. Scatter plot of observed and simulated stream flow for Kulfo River during calibration period.

\subsubsection{Validation of Monthly Stream Flow}

Validation is evaluation of the model outputs with an independent data set without making further adjustments. The process is to confirm that the simulation is good enough that the validation was carried out using the calibrated parameters [29]. For model validation the reaming observed stream flow of Kulfo hydrological station was used. In the validation process the model was run with a parameter set without any change of the parameter during the calibration process. The four performance indicators during the calibration were again used in the validation period to evaluate the performance of the model. The Validation result showed that the coefficient of determination $\left(\mathrm{R}^{2}\right)$ and the Nash-Sutcliff efficient (NSE) are 0.92 and 0.78 respectively. These are according to Moriasi suggestion the performance rating is Very good for both $\mathrm{R}^{2}$ and NSE [27]. The Standard Deviation Ratio (RSR) and Percent Bias (PBIAS) is 0.46 and $21 \%$ which is under Very good and satisfactory range respectively. The time series data of the observed and simulated flows on monthly basis were plotted for comparison (Figure 5). The scatter plot value of the measured and simulated flow has shown a linear correlation between the data sets (figure 6)

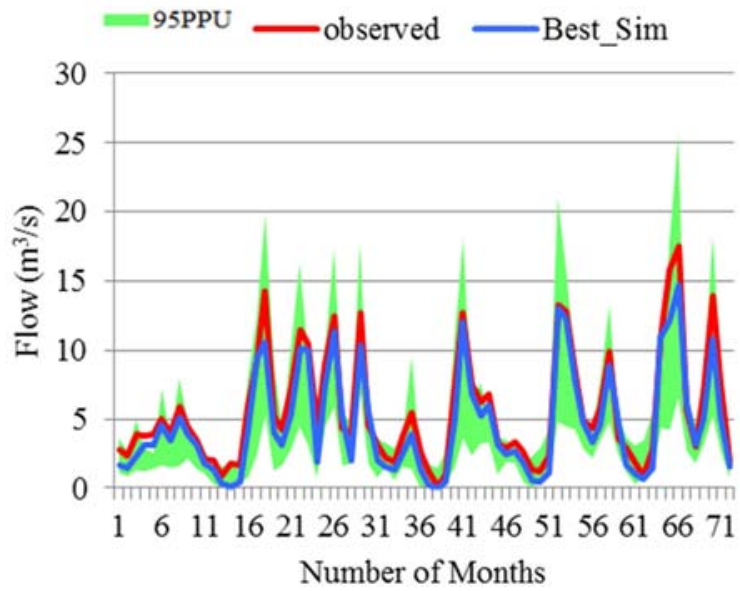

Figure 5. Average monthly observed and simulated stream flow of Kulfo River during the validation period (2006-2011).

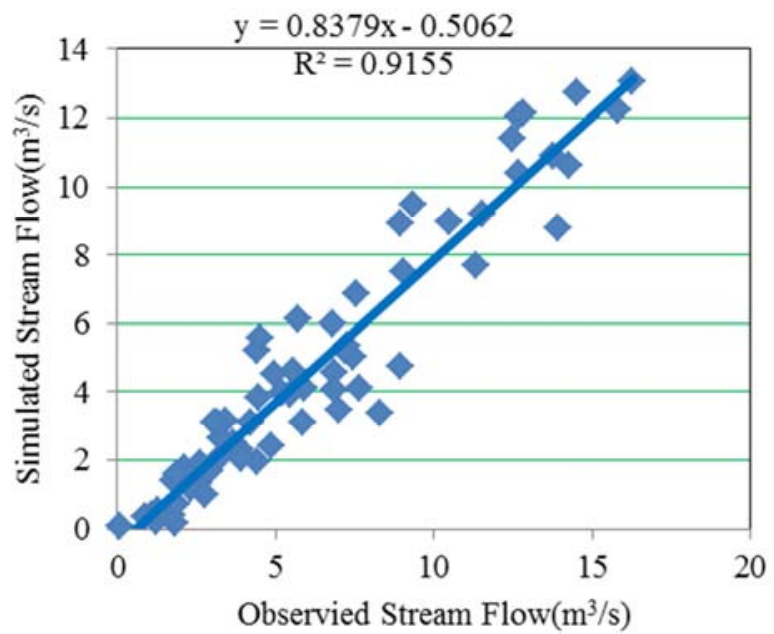

Figure 6. Scatter plot of observed and simulated stream flow of Kulfo River during validation period.

Generally, the Stream flow calibration and validation results on monthly basis obtained from SWAT-CUP, SUFI-2 were summarized in table 3 as follows:

Table 3. Stream flow calibration and validation results on monthly basis (Model performance evaluation results).

\begin{tabular}{lll}
\hline Variable & Calibration & Validation \\
\hline $\mathrm{R}^{2}$ & 0.81 & 0.92 \\
$\mathrm{NSE}$ & 0.68 & 0.78 \\
$\mathrm{RSR}$ & 0.57 & 0.46 \\
PBIAS & 20 & 21 \\
Measured Average monthly flow $\left(\mathrm{m}^{3} / \mathrm{s}\right)$ & 4.79 & 5.89 \\
Simulated Average monthly flow $\left(\mathrm{m}^{3} / \mathrm{s}\right)$ & 3.65 & 4.43 \\
\hline
\end{tabular}

The strong correlation between the measured flow and the simulated (figure 4 and 6) showed that the generation of stream flow in the Kulfo River is well captured by the model during both calibration and validation. However, according to [30] the model underestimated meaning the simulated average monthly flow $\left(3.65 \mathrm{~m}^{3} / \mathrm{s}\right)$ compared to the measured flow (4.79 $\mathrm{m}^{3} / \mathrm{s}$ ) during calibration and the simulated average monthly flow $\left(4.43 \mathrm{~m}^{3} / \mathrm{s}\right)$ compared to the measured flow $\left(5.89 \mathrm{~m}^{3} / \mathrm{s}\right)$ during Validation. In general, the results indicate that SWAT is a capable model to estimate stream flow in the study area. Therefore; the calibrated model was used to assess the response of stream flow to future climate change with reasonable degree of confidence.

\subsection{Assessment of the Potential Impact of Climate Change on Stream Flow of Kulfo River}

In this study, the analysis of climate change impact on stream flow has been focused on predicting the potential impacts that changes in temperature and rainfall will cause on stream flow. For this purpose, two simulation sets were performed.

i. Evaluation of the effect caused in stream flow by changes in each of the variables (temperature and rainfall).

ii. Analyses of the response of stream flow to combine 
effect of the two variables.

\subsubsection{Stream Flow Sensitivity Analysis}

The changes in discharge under the impact of climate change were investigated by using several hypothetical scenarios (synthetic approach) applied to the base line period (1987-2014) meteorological data. A hypothetical temperature increase $\left(0^{\circ} \mathrm{C},+2.5^{\circ} \mathrm{C},+3^{\circ} \mathrm{C}\right)$ for the year $2050 \mathrm{~s}$ and $\left(0^{\circ} \mathrm{C},+4{ }^{\circ} \mathrm{C},+4.5^{\circ} \mathrm{C}+5^{\circ} \mathrm{C}\right)$ for the year $2080 \mathrm{~s}$ with precipitation change $(-20 \%$ to $+20 \%)(10 \%$ increment $)$ is applied based on IPCC fifth assessment report [12] and previous studies on climate to examine the change of the SWAT simulated monthly stream flow. A detailed analysis of change in temperature $(\Delta \mathrm{T})$ and precipitation $(\Delta \mathrm{P})$ impact on stream flow of Kulfo River for the year 2050s and 2080s are separately discussed as follows:

Table 4. Results of mean annual discharge $\left(\mathrm{m}^{3} / \mathrm{s}\right)$ due to changes in temperature and precipitation for the year $2050 \mathrm{~s}$.

\begin{tabular}{llllll}
\hline$\Delta \mathbf{P}$ & $\mathbf{- 2 0 \%}$ & $\mathbf{- 1 0 \%}$ & $\mathbf{0 \%}$ & $\mathbf{1 0 \%}$ & $\mathbf{2 0 \%}$ \\
\hline$\Delta \mathrm{T}(0)$ & 8.9852 & 9.2152 & 9.4497 & 9.8113 & 9.9812 \\
$\Delta \mathrm{T}\left(\mathrm{T}+2.5^{\circ} \mathrm{C}\right)$ & 8.9606 & 9.1882 & 9.1956 & 9.7915 & 9.9619 \\
$\Delta \mathrm{T}\left(\mathrm{T}+3^{\circ} \mathrm{C}\right)$ & 8.8252 & 8.9985 & 9.1798 & 9.6954 & 9.8634 \\
\hline
\end{tabular}

Table 5. Results of changes in mean annual discharge (\%) due to the changes in temperatures and precipitation for the year 2050s.

\begin{tabular}{llllll}
\hline$\Delta \mathbf{P}$ & $\mathbf{- 2 0} \%$ & $\mathbf{- 1 0 \%}$ & $\mathbf{0 \%}$ & $\mathbf{1 0 \%}$ & $\mathbf{2 0 \%}$ \\
\hline$\Delta \mathrm{T}(0)$ & -4.92 & -2.48 & 0 & 3.83 & 5.2 \\
$\Delta \mathrm{T}\left(\mathrm{T}+2.5^{\circ} \mathrm{C}\right)$ & -5.18 & -2.767 & -2.69 & 3.6 & 5.1 \\
$\Delta \mathrm{T}\left(\mathrm{T}+3^{\circ} \mathrm{C}\right)$ & -6.6 & -4.775 & -2.86 & 2.6 & 4.38 \\
\hline
\end{tabular}

Table 6. Results of mean annual discharge $\left(\mathrm{m}^{3} / \mathrm{s}\right)$ due to changes in temperature and precipitation for the year 2080s.

\begin{tabular}{llllll}
\hline$\Delta \mathbf{P}$ & $\mathbf{- 2 0 \%}$ & $\mathbf{- 1 0 \%}$ & $\mathbf{0 \%}$ & $\mathbf{1 0 \%}$ & $\mathbf{2 0 \%}$ \\
\hline$\Delta \mathrm{T}\left(\mathrm{T}+4^{\circ} \mathrm{C}\right)$ & 8.8754 & 9.1657 & 9.1856 & 9.7084 & 9.9615 \\
$\Delta \mathrm{T}\left(\mathrm{T}+4.5^{\circ} \mathrm{C}\right)$ & 8.7957 & 9.1568 & 9.1758 & 9.6987 & 9.9517 \\
$\Delta \mathrm{T}\left(\mathrm{T}+5^{\circ} \mathrm{C}\right)$ & 8.6792 & 9.1498 & 9.1674 & 9.5987 & 9.9416 \\
\hline
\end{tabular}

Table 7. Results of changes in mean annual discharge (\%) due to changes in temperature and precipitation for the year 2080s.

\begin{tabular}{llllll}
\hline$\Delta \mathbf{P}$ & $\mathbf{- 2 0} \%$ & $\mathbf{- 1 0 \%}$ & $\mathbf{0 \%}$ & $\mathbf{1 0 \%}$ & $\mathbf{2 0 \%}$ \\
\hline$\Delta \mathrm{T}\left(\mathrm{T}+4^{\circ} \mathrm{C}\right)$ & -6.08 & -3.01 & -2.80 & 2.74 & 5.42 \\
$\Delta \mathrm{T}\left(\mathrm{T}+4.5^{\circ} \mathrm{C}\right)$ & -6.92 & -3.1 & -2.90 & 2.64 & 5.31 \\
$\Delta \mathrm{T}\left(\mathrm{T}+5^{\circ} \mathrm{C}\right)$ & -8.2 & -3.2 & -2.99 & 2.09 & 5.21 \\
\hline
\end{tabular}

\subsubsection{Sensitivity to Precipitation Change for the Year 2050s}

For Kulfo River changes in average annual stream flow due to the changes in precipitation, while holding the temperature constant are shown in Figure 7, table 4 and table 5. Different precipitation scenarios are analyzed which include $-20 \%$ to $+20 \%$ to the base period of $1987-2014$. Mean monthly discharge for variable precipitation while fixing temperature constant is shown in Figure 8. It is observed that the peak discharge is found in May and October in almost all cases.
Changes in annual mean $\Delta \mathrm{Q}(\%)$

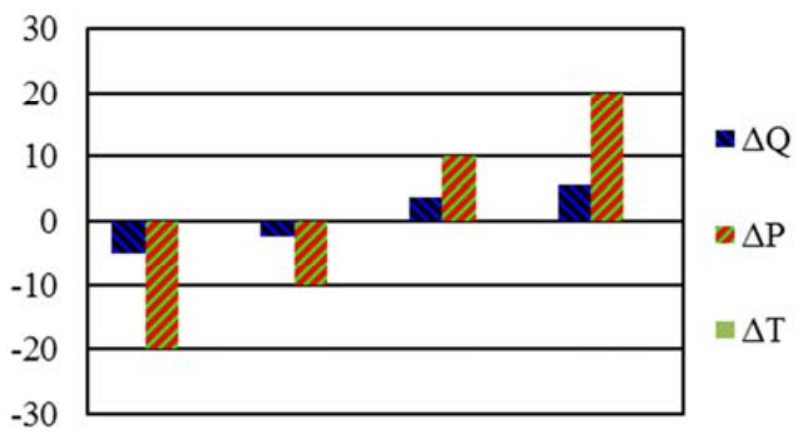

Figure 7. Changes in annual mean stream flow (\%) of Kulfo River due to changing in $\Delta P=-20 \%$ to $+20 \%$ and $\Delta T=0$ for $2050 \mathrm{~s}$.

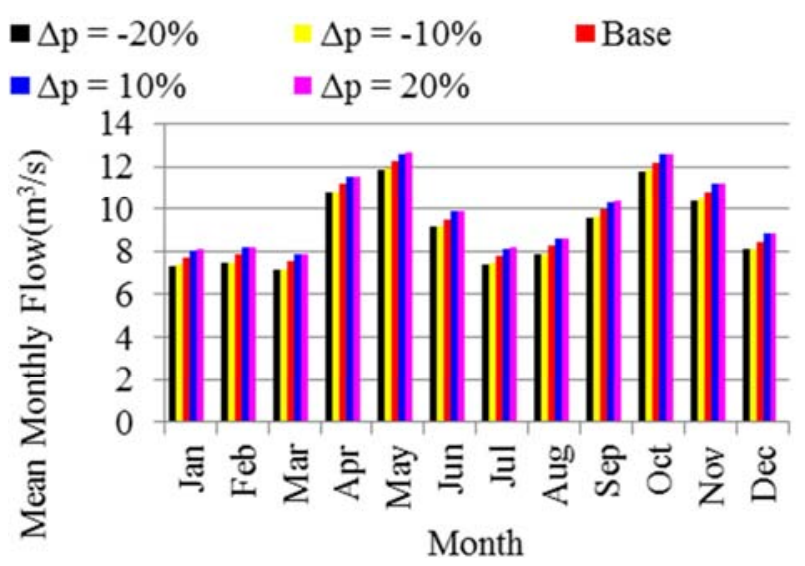

Figure 8. Mean monthly stream flow of Kulfo River due to $\Delta P=-20 \%$ to $+20 \%$ and $\Delta T=0$ for 2050 s.

\subsubsection{Sensitivity to Temperature Change for the Year 2050s}

The relative sensitivity of stream flow to the changes in temperature, while keeping the precipitation unchanged, gives a moderate changes in stream flow as compare to the changes due to precipitation (Figure 9, table 4 and table 5). The sensitivity was found non-linear. Mean monthly discharge for variable temperature holding precipitation constant is shown in Figure 9. It is observed that the peak discharge is found in May and October. Changes in monthly mean discharge is shown in Figure 10. Discharge is found to decrease in all cases due to increase in temperature.

\section{Change in $\Delta \mathrm{Q}(\%)$ for $\Delta \mathrm{P}=0 \%$ and $\Delta \mathrm{T}=2.5$} $\& 3^{\circ} \mathrm{C}$

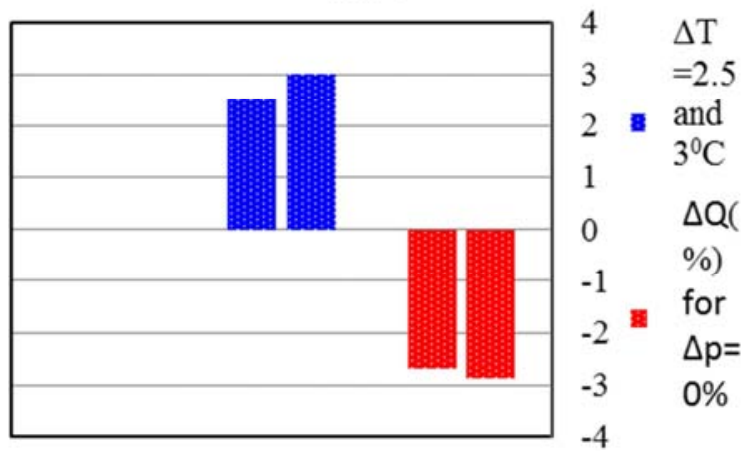

Figure 9. Change in mean annual stream flow (\%) due to change in temperature for constant precipitation for $2050 \mathrm{~s}$. 


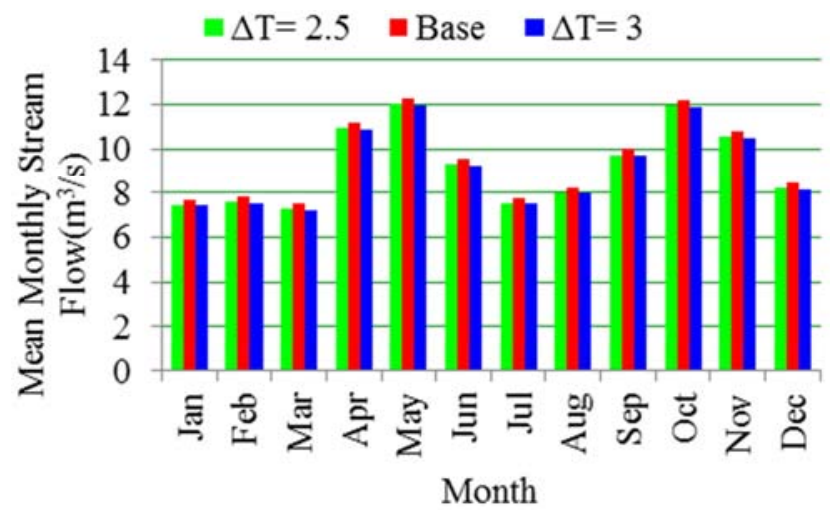

Figure 10. Mean monthly discharge $\left(\mathrm{m}^{3} / \mathrm{s}\right)$ for variable temperature holding precipitation constant for 2050 s.

\subsubsection{Sensetivity to Temperature Change for the Year 2080s}

The relative sensitivity of stream flow to the changes in temperature, while holding the precipitation constant for the year 2080s also assessed with similar procedure for the year $2050 \mathrm{~s}$ in the above section. The results also indicate that the discharge is found to decrease in all cases due to increase in temperature and evaporation all over the River.

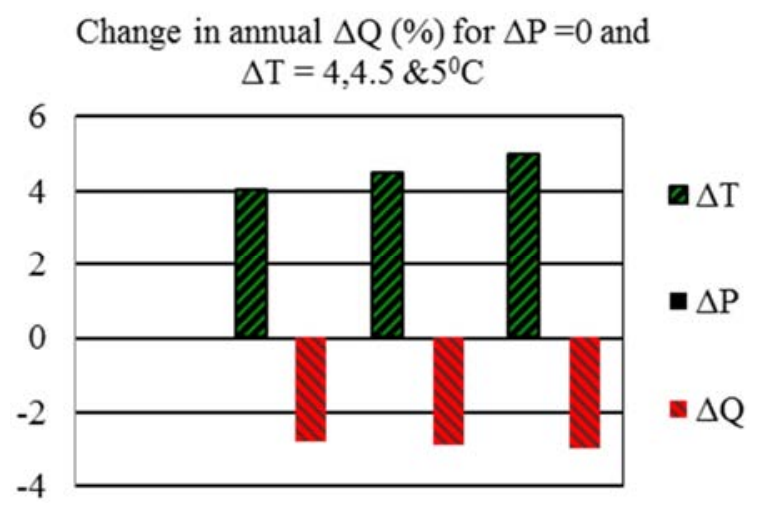

Figure 11. Changes in annual $Q$ (\%) of Kulfo River due to changing in temperature holding precipitation constant for $2080 \mathrm{~s}$.

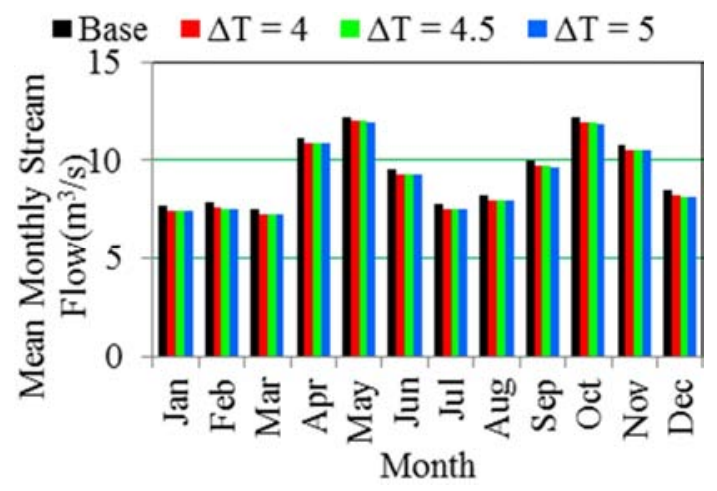

Figure 12. Mean monthly discharge $\left(\mathrm{m}^{3} / \mathrm{s}\right)$ for variable temperature for constant precipitation $(\Delta P=0 \%)$ for 2080 s.

\subsubsection{Sensetivity to The Combined Effect of Temperature and Precipitation}

Sensitivity of the stream flow when both temperature and precipitation changes were also analyzed. Combination of temperature change $\left(0^{\circ}, 2.5^{\circ}\right.$ and $\left.3^{\circ} \mathrm{C}\right)$ with the change of precipitation $(-20 \%$ to $+20 \%)$ for the year 2050 s and $\left(0^{\circ}, 4^{\circ}\right.$, $4.5^{\circ}$ and $5^{\circ} \mathrm{C}$ ) for the year $2080 \mathrm{~s}$ were considered. Figure 13 and 14 and table 4, 5, 6 and 7 shows that the change in $\Delta Q$ is very much small and no rapid increase or decrease in the flow has been found for temperature change holding precipitation constant.

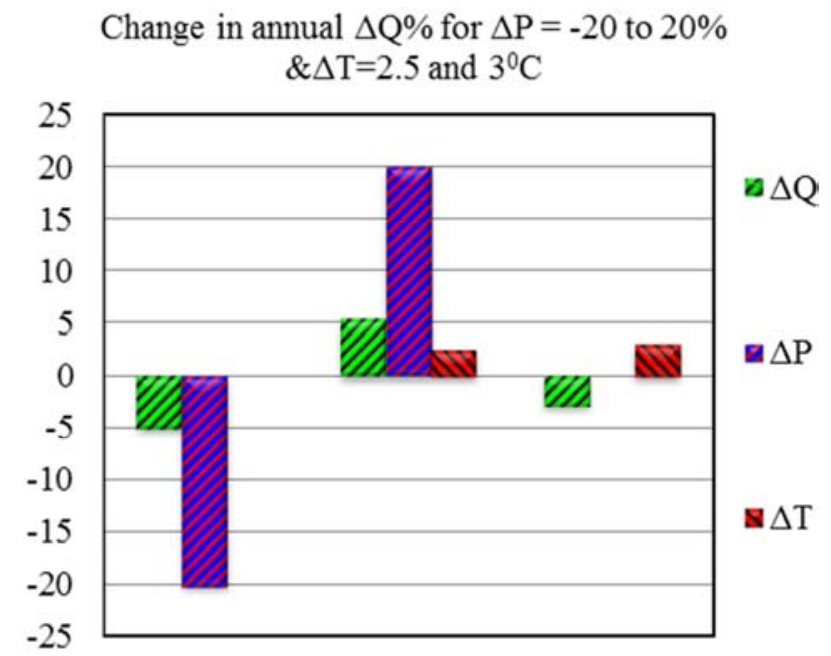

Figure 13. Changes in annual discharge (\%) of Kulfo River due to changing in both $\Delta P$ and $\Delta T$ for 2050 s.

Change in annual $\Delta \mathrm{Q} \%$ for $\Delta \mathrm{P}=-20,10 \& 20 \%$ $\& \Delta \mathrm{T}=4,4.5 \& 5^{\circ} \mathrm{C}$

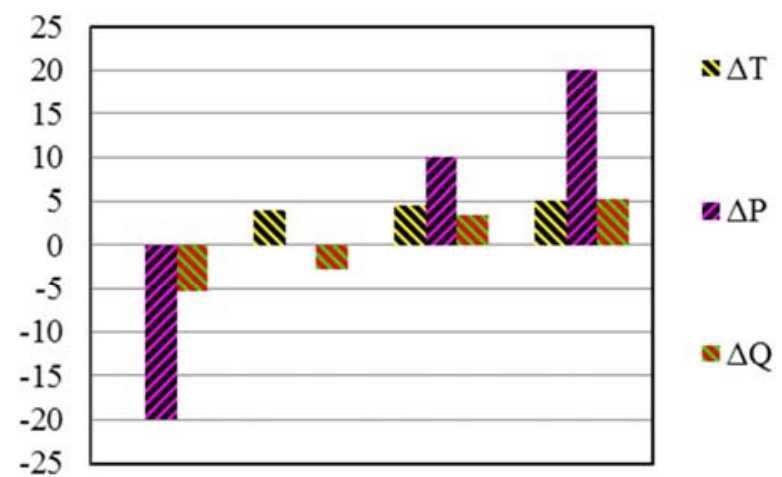

Figure 14. Changes in annual discharge (\%) of Kulfo River due to changing in both $\Delta P$ and $\Delta T$ for 2080 s.

\subsection{Climate Change Impact on Flow of Kulfo River}

Compared to the baseline period flow, the average annual stream flow of Kulfo River is increase by $5.2 \%$ (for $\Delta \mathrm{T}=0$ and $\Delta \mathrm{P}=20 \%$ ) scenarios in the year 2050s. Similarly it is increase by $6.82 \%(\Delta \mathrm{T}=0$ and $\Delta \mathrm{P}=20 \%)$ scenarios in the year $2080 \mathrm{~s}$. But, when $\Delta \mathrm{T}=3{ }^{\circ} \mathrm{C}$ and $\Delta \mathrm{P}=-20 \%$ (worst case scenario) it was found to give the maximum reduction in discharge about $-6.6 \%$ compared to the base line flow in 2050s. Again in 2080s, when $\Delta \mathrm{T}=5^{\circ} \mathrm{C}$ and $\Delta \mathrm{P}=-20 \%$ (worst case scenarios) it was found that the maximum reduction in discharge about $-8.2 \%$ compared to the base line flow. These are due to projected changes to the primary climatic factors (temperature and precipitation). SWAT simulated the mean annual and monthly stream flow for projected climate change scenarios. It was 
found that the discharge of Kulfo River is more increasing when precipitation increasing and decreasing when temperature increasing over the $21^{\text {st }}$ century. The results show that the increased precipitation usually causes an increase in discharge while the increased temperature causes decrease in discharge by increasing evaporative losses. These results are close to those obtained by Anwar who analyzed the climate change impact on stream flow in the upper Gilgel Abay Catchment, Blue Nile basin Ethiopia using the SDSM [31]. These authors predicted the increase in climate variable (temperature and precipitation) increase mean annual stream flow by $7.9 \%$ and $6.4 \%$ for 2050 s and 2080 s under B2 scenario.

Finally, for this particular study, increasing temperature by $0.5^{\circ} \mathrm{C}$ from $\left(2.5^{\circ} \mathrm{C}\right.$ to $\left.3^{\circ} \mathrm{C}\right)$ and from $4.5^{\circ} \mathrm{C}$ to $5^{\circ} \mathrm{C}$, the maximum decreased in stream flow rates by $2.86 \%$ in $2050 \mathrm{~s}$ and $2.99 \%$ in $2080 \mathrm{~s}$; while $10 \%$ (from $-10 \%$ to $-20 \%$ ) drops in rainfall resulted in a stream flow reduce by $4.92 \%$ and $5.28 \%$ in 2050s and 2080s respectively. These results indicate that stream flow in the Kulfo River will be more sensitive to change in" precipitation" than to change in temperature. This result is consistent with [32-36] who have shown that rainfall is the primary atmospheric factor that directly affects the stream flow patterns. In contrast, there are also studies which are dis agreement with our findings (e.g. [37-40]) who found that changes in rainfall are not sufficient to explain the trends in the stream flow.

\section{Conclusion}

A SWAT hydrological model calibration and validation guided by sensitivity analysis. The sensitivity analysis pointed out eight most critical parameters that control the surface, sub-surface and evaporation hydrological processes of the studied area. The result of hydrological model calibration and validation indicated that the SWAT model simulates the flow significantly well for the study area. The model performance criterion which is used to evaluate the model result, the regression coefficient $\left(\mathrm{R}^{2}=0.81\right.$ and 0.92$)$ and the Nash-Sutcliffe simulation efficiency ( $\mathrm{NSE}=0.68$ and 0.78 ) gained during calibration and validation respectively showed this fact.

The stream flow sensitivity analysis indicates that Kulfo River is more sensitive to precipitation than temperature change. Compared to current (1987-2014) condition, the projected precipitation by $+10 \%$ the maximum projected increase in discharge of $5.2 \%$ was found for $2050 \mathrm{~s}$ and $6.82 \%$ for 2080s. But, when temperature is $+3^{\circ} \mathrm{C}$ and $+5^{\circ} \mathrm{C}$ the maximum projected decrease in discharge occur which is $-2.86 \%$ in 2050 s and $-2.99 \%$ in 2080 s respectively.

\section{References}

[1] Bates B., K. C., WU W., Palutiko FP. (EDS) Climate change and water Technical Paper of the Intergovernmental Panel on Climate Change. Geneva, Switzerland, IPCC Secretariat 2008: p. 210 .
[2] Hunt A, W. P., Climate change impacts and adaptation in cities a review of the literature. Clim Chang 2011. 104: p.13-49. doi:10.1007/s10584-010-9975-6.

[3] IPCC, Climate Change 2014: Synthesis Report. Contribution of Working Groups I, II and III to the Fifth Assessment Report of the Intergovernmental Panel on Climate Change Core Writing Team, R. K. Pachauri and L. A. Meyer (eds.). IPCC, Geneva, Switzerland, 2014: p. 151.

[4] Abdella, The Effect of Climate Change on Water Resources Potential of Omo Gibe Basin, Ethiopia 2013: p. 200.

[5] IPCC, statement on the melting of Himalayan glaciers $A$ statement from the Chair and Vice-Chairs of the IPCC, and the Co-Chairs of the IPCC Working Groups 2010.

[6] Setegn, S. G., D. Rayner, A. M. Melesse, B. Dargahi, and R. Srinivasan, Impact of climate change on the hydroclimatology of Lake Tana Basin, Ethiopia. Water Resour. Res., (2011). 47: p. W04511, doi:10.1029/2010WR009248.

[7] Ethiopian Mapping Authority, N. A., Addis Ababa, Ethiopia: Ethiopian Mapping Authority 1988.

[8] Ayenew, Recent changes in the level of Lake Abiyata, central main Ethiopian Rift. Hydrological Sciences Journal, 2002. 47 (3) p. 493-503.

[9] Ayalkibet, Evaluation of impacts of Soil and water Conservation on Watershed hydrology of Kulfo River Using Hydrological SWAT Models, SNNPR International Journal of Scientific \& Engineering Research 2016. 7 (8): p. 2229-5518.

[10] Stefan, B. a., Kulfo River, South-Ethiopia as the regulator of lake level chananges in the Lake Abaya-Lake Chamo system. 2006: p. 129-143.

[11] Neitch, S. L., Arnold, J. R., Kiniry, J. R., \& Williams, J. R., Soil and Water Assessment Tool (SWAT) Theoretical Documentation Version2009 Texas Water Resources Institute Technical Report No. 406, Texas A\&M University System, College Station, Texas, 2011.

[12] IPCC, Climate Change 2014. Syntetic report Contribution of working groups I, II and III to the fifth assesement Report of the Intergovernmental Panel on climate change, 2014: p. 151.

[13] Abraham Mechal, T. W., Steffen Birk, Recharge variability and sensitivity to climate: The exampleof Gidabo River Basin, Main Ethiopian Rift. Journal of Hydrology Regional Studies 2015. 4 (2015): p. 644-660.

[14] Habtom, Evaluation of Climate Change Impact on Upper Blue Nile Basin Reservoirs (Case Study on Gilgel Abay Reservoir, Ethiopia). 2009.

[15] Arnold, J. G., Srinivasan, R., Muttiah, R. S., \& Williams, J. R, Large Area Hydrologic Modeling and Assessment Part I: Model Development. Journal of the American Water Resources Association, 1998. 34 (1),: p. 73-89. Retrieved from http://doi.wiley.com/10.1111/j.1752-1688.1998.tb05961.x doi: 10.1111/j.1752-1688 1998.tb05961.x.

[16] Arnold, J. G., Haney, E. B., Kiniry, J. R., Neitsch, S. L., Srinivasan, R., Neitsch, S. L., \& Williams, J. R., Soil and Water Assessment Tool (SWAT) theoretical documentation version 2012. Texas Water Resources Institute Technical Report No. 439: pp650. College Station, Texas 2012. 
[17] Neitch, S. L., Arnold, J. R., Kiniry, J. R., \& Williams, J. R Soil and Water Assessment Tool (SWAT) Theoretical Documentation Version2009 Texas Water Resources Institute Technical Report No. 406, Texas A\&M University System, College Station, Texas, 2011.

[18] SCS, Section 4 Hydrology. In National engineering handbook, 1972.10 (22): p. 10-1 -10-22.

[19] Green, W. H., \& Ampt, G., Studies on soil physics, 1. the ow of air and water through soils. J. Agric. Sci, 1911. 4 (1): p. 1-24.

[20] Abbaspour, K. C., Yang, J., Maximov, I., Siber, R., Bog-ner, K., \& Mieleitner, J., Spatially Distributed Modelling of Hydrology and Water Quality in the Prealpine/Alpine Thur Watershed Using SWAT Journal of Hydrology 2007. 333 (2-4): p. 413-430.

[21] Yang J, R. P., Abbaspour K, Xia J, Yang H, Comparing uncertainty analysis techniques for a SWAT application to the Chaohe Basin in China. J. Hydrol 2008. 358: p. 1-23.

[22] Abbaspour, K. C., User Manual for SWAT-CUP, SWAT Calibration and Uncertainty Analysis Programs Swiss Federal Institute of Aquatic Science and Technology. Duebendorf, Switzerland 2015: p. 101.

[23] Van de Giesen, N., Liebe, J., \& Jung, G., Adapting to climate change in the volta basin, west africa. Current science, 2010. 98 (8): p. 1033-1037.

[24] Kassa, Watershed Hydrological Responses to Changes in Land Use and Land Cover, and Management Practices at Hare Watershe. Ethiopia PHD thesis. University of Siegen, Germany 2009.

[25] Neitsch, S. L., Arnold, J. G., Kiniry, J. R., \& Williams, J. R., Soil and Water Assessment Tool. Theoretical Documentation Version 2005. Temple, TX. USDA 2005.

[26] Goswami, M., K. M. O'Connor, Bhattari, K. \& Shamseldin, A., Assessing the performance of eight real-time updating models and procedures for the Brosna River. Hydrology and the Earth system Sciences 2005.9 (4): p. $394-411$.

[27] Moriasi, D., Arnold, J., Van Liew, M., Bingner, R., Harmel, R., \& Veith, T., Model evaluation guidelines for systematic quanti cation of accuracy in watershed simulations. Trans, Asabe, 2007. 50 (3): p. 885-900.

[28] Nash JE, S. J., River flow forecasting through conceptual models: part I-a discussion of principles. J Hydrol, 1970. 10: p. 282-290.

[29] Kassa, T., Watershed Hydrological Responses to Changes in Land Use and Land Cover, and Management Practices at Hare Watershed, Ethiopia PHD thesis. University of Siegen, Germany 2009.
[30] Komlavi, Impact of Rainfall Variability, Land Use and Land Cover Change on Stream Flow for Hydropower Generation in the Black Volta Basin. 2015.

[31] Anwar. A, S., Tilahun, Essayas, Ayana, Abeyou, Worqlul, Tewodros, Assefa, Shimelis, Dessu, Assefa, Climate Change Impact on Stream flow in the UpperGilgelAbayCatchment, BlueNilebasin, Ethiopia. Springer-Verlag, Berlin/Heidelberg, 2015.

[32] Tesfay G. Gebremicael, Y. A. M., Pieter, Zaag and Eyasu Y. Hagos, Temporal and spatial changes of rainfall and streamflow in the Upper Tekez Atbara river basin, Ethiopia. Hydrology and Earth System Scence, 2017. 21: p. 2127-2142.

[33] Shi, W., Yu, X., Liao, W., Wang, Y., and Jia, B, Spatial and temporal variability of daily precipitation concentration in the Lancang River basin. China, J. Hydrol, 2013. 495: p. 197-207.

[34] Tesemma, Z. K., Mohamed, Y. A., and Steenhuis, T. S, Trends in rainfall and runoff in the Blue Nile Basin. Hydrol Process, 2010. 24: p. $3747-3758$.

[35] Zhao, J., Huang, Q., Chang, J., Liu, D., Huang, S. and Shi, X, Analyses of temporal and spatial trends of hydro-climatic variables in the Wei River Basin, Environ. Environ Res, 2015. 139: p. 55-64.

[36] Piniewski, M. S. a. M., Improvement of Hydrological Simulations by Applying Daily Precipitation Interpolation Schemes inMeso-Scale Catchments. Water, 2015.7 (ISSN 2073-4441): p. 747-779; doi:10.3390/w7020747.

[37] Tekleab, S., Mohamed, Y., and Uhlenbrook, S, Hydro-climatic trends in the Abay/Upper Blue Nile basin, Ethiopia. Phys Chem Earth A/B/C, 2013: p. 61-62, 32-42.

[38] Gebremicael, T. G., Mohamed, Y. A., Betrie, G. D., van der Zaag, P., and Teferi, E, Trend analyses of runoff and sediment fluxesin the Upper Blue Nile basin:A combined analyses of statistical tests, physically based models and landuse maps. J. Hydrol, 2013.482:p. 57-68.

[39] Hannaford, J., Climate-driven changes in UK river flows, A review of the evidence. Prog. Phys. Geogr, 2015. 39: p. 29-48.

[40] Saraiva Okello, A. M. L., Masih, I., Uhlenbrook, S., Jewitt, G. P. W., van der Zaag, P., and Riddell, E, Drivers of spatial and temporal variability of streamflow in the Incomati River basin. Hydrol. Earth Syst. Sci, 2015. 19: p. 657-673, doi:10.5194/hess-19-657-2015. 